\title{
Turbiditic trench deposits at the South-Chilean active margin: A Pleistocene-Holocene record of climate and tectonics
}

\author{
S. Blumberg ${ }^{\text {a,b,*}}{ }^{\text {F. Lamy }}{ }^{\text {c }}$, H.W. Arz ${ }^{\text {a }}$, H.P. Echtler ${ }^{\text {a }}$, M. Wiedicke ${ }^{\text {d }}$, \\ G.H. Haug ${ }^{\mathrm{b}, \mathrm{e}}$, O. Oncken ${ }^{\mathrm{a}}$

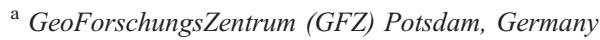 \\ ${ }^{\mathrm{b}}$ Leibniz Center for Earth Surface and Climate Studies at the University of Potsdam, Germany \\ c Alfred-Wegener-Institut für Polar- und Meeresforschung (AWI) Bremerhaven, Germany \\ ${ }^{\mathrm{d}}$ Bundesanstalt für Geowissenschaften und Rohstoffe (BGR) Hannover, Germany \\ e Eidgenössische Technische Hochschule (ETH) Zürich, Switzerland
}

Received 1 August 2007; received in revised form 6 February 2008; accepted 6 February 2008 Available online 19 February 2008

Editor: M.L. Delaney

\begin{abstract}
The active plate margin of South America is characterized by a frequent occurrence of large and devastating subduction earthquakes. Here we focus on marine sedimentary records off Southern Chile that are archiving the regional paleoseismic history over the Holocene and Late Pleistocene. The investigated records - Ocean Drilling Program (ODP) Site 1232 and SONNE core 50SL - are located at $\sim 40^{\circ} \mathrm{S}$ and $\sim 38^{\circ} \mathrm{S}$, within the Perú-Chile trench, and are characterized by frequent interbedded strata of turbiditic and hemipelagic origin. On the basis of the sedimentological characteristics and the association with the active margin of Southern Chile, we assume that the turbidites are mainly seismically triggered, and may be considered as paleo-megaearthquake indicators. However, the long-term changes in turbidite recurrence times appear to be strongly influenced by climate and sea level changes as well. During sea level highstands in the Holocene and Marine Isotope Stage (MIS) 5, recurrence times of turbiditic layers are substantially higher, primarily reflecting a climate-induced reduction of sediment availability and enhanced slope stability. In addition, segmented tectonic uplift changes and related drainage inversions likely influenced the postglacial decrease in turbidite frequencies. Glacial turbidite recurrence times (including MIS 2, MIS 3, cold substages of MIS 5, and MIS 6), on the other hand, are within the same order of magnitude as earthquake recurrence times derived from the historical record and other terrestrial paleoseismic archives of the region. Only during these cold stages sediment availability and slope instability were high enough to enable recording of the complete sequence of large earthquakes in Southern Chile. Our data thus suggest that earthquake recurrence times on the order of 100 to 200 years are a persistent feature at least during the last glacial period.
\end{abstract}

(C) 2008 Elsevier B.V. All rights reserved.

Keywords: turbidite frequency; earthquake recurrence; Chile active margin; trench deposits; paleoseismology; paleoclimate

\section{Introduction}

Submarine slopes at active convergent plate margins are preferential regions for the generation of large-scale turbidity currents. In the trench sediment records the deposits of these

\footnotetext{
* Corresponding author. GFZ Potsdam, Telegrafenberg, 14473 Potsdam, Germany. Tel.: +49 331 2881355; fax: +49 3312881302 .

E-mail address: sblumb@gfz-potsdam.de (S. Blumberg).
}

underwater mass movements are interbedded as clearly identifiable turbiditic layers within the otherwise (hemi-) pelagic sediments. Assuming that the turbidity currents within seismically active regions are predominantly earthquaketriggered, the appropriate turbidite records can be used for paleoseismic investigations. Recently, this approach has been successfully applied for instance in Cascadia (Adams, 1996; Goldfinger et al., 2003; Goldfinger et al., 2007), Saanich Inlet in British Columbia (Blais-Stevens and Clague, 2001), California 
(Gorsline et al., 2000), Northern Chile (Vargas et al., 2005), Taiwan (Huh et al., 2004) and Japan (Inouchi et al., 1996; Nakajima and Kanai, 2000).

In this study, we applied the approach to the area of Southern Chile by using turbiditic sequences as paleoseismic records. The tectonically active region of Southern Chile along the convergent continental margin is characterised by high deformation rates, uplift and subsidence, and severe earthquakes, including the strongest event ever recorded from 1960 with a magnitude of 9.5 (Plafker and Savage, 1970). Paleoseismic studies in Southern Chile so far focus on coseismically uplifted beach berms (Nelson and Manley, 1992; Bookhagen et al., 2006), their active and longer term tectonic context (Melnick et al., 2006), sedimentary tsunami horizons (Cisternas et al., 2005) as well as on historical evidence of earthquakes and their secondary effects (Lomnitz, 1970, 2004). Based on these different archives, the earthquake recurrence intervals in South-Central Chile are fairly discussed for the mid to Late Holocene but, as elsewhere, are hardly investigated for older periods, e.g. the Pleistocene. Here, we present the first paleoseismic study covering a complete glacial to interglacial cycle. Due to its position in front of the active continental margin of Southern Chile the marine sedimentary record of ODP Site 1232 is well suited for a paleoseismicity study. Late Pleistocene in age, the succession is characterised by hemipelagic sediments with frequently interbedded turbiditic deposits.

Climatic and hydrologic conditions of Southern Chile have influenced sedimentation since the onset of the glaciation in the Patagonian Andes six million years ago. Since then, the sediment influx to the Chile Trench south of the Juan-Fernández Ridge has increased tremendously and induced persistent accretion and subduction of terrigenous material (Bangs and Cande, 1997; Melnick and Echtler, 2006a). In particular, the climate variations during the Pleistocene period affected the sedimentation rate and pattern on- and offshore (Lamy et al., 2001, 2002, 2004; Hebbeln et al., 2007). Our study suggests that these climate changes and related sea level variations over the last glacial to interglacial cycle impacted particularly the long-term pattern of earthquake recurrence as recorded in the submarine sediment sequence: Only during cold stages of the past $140 \mathrm{kyr}$, sediment availability and slope instability were high enough to allow recording of the complete sequence of large earthquakes in Southern Chile.

\section{Investigation area}

\subsection{Tectonic and bathymetry}

The active margin of Southern Chile is part of the convergence zone between the oceanic Nazca Plate and the South American continent. The oblique subduction of the Nazca Plate is taking place at a rate of $66 \mathrm{~mm} / \mathrm{yr}$ (Angermann et al., 1999) forming the long range of the Andes as well as the outstanding depression of the Perú-Chile trench. Between the Juan Fernández Ridge in the north $\left(34^{\circ} \mathrm{S}\right)$ and the Chile Rise in the south $\left(46^{\circ} \mathrm{S}\right)$, the trench is filled by sediments of partly more than $2 \mathrm{~km}$ thickness (Fig. 1) locally appearing rather as a flat plain than as a bathymetric depression (Miller, 1976; Schweller et al., 1981; Bangs and Cande, 1997).

The trench infill is composed of interbedded turbiditic and hemipelagic strata which show certain cyclicity in their overall seismic reflection pattern interpreted to express the influence of global climate cycles on sedimentation (Rauch, 2005; Völker et al., 2006). Since the onset of glacial erosion and denudation in the Andes about six million years ago the trench fill sediments controlled the subduction dynamics, changing the formerly erosive to an accretionary margin (Melnick and Echtler, 2006a). The excess trench sediments moreover smoothed out the surface of the subducting plate with a lubricating effect on the plate interface. That way, the trench fill sediments and the consequent subduction channel enhance the occurrence of great subduction earthquakes since it is allowing the rupture to disperse over a wider zone (Ruff, 1989; Lamb and Davis, 2003). On this account, the Southern Chilean margin is periodically affected by devastating earthquakes of $M>8$ (Lomnitz, 1970, 2004), including the prominent $M_{\mathrm{W}} 9.5$ Valdivia event in 1960 which ruptured about $1000 \mathrm{~km}$ of the Chilean forearc between $\sim 37^{\circ}$ and $46^{\circ} \mathrm{S}$ (Plafker and Savage, 1970) (Fig. 1). Even though this widespread rupture zone indicates a rather homogenous plate interface, the long-term morphotectonic evolution of the Chilean forearc appears to be highly complex (Rehak et al., 2008). Between $36^{\circ}$ and $42^{\circ} \mathrm{S}$, the Chilean forearc is characterized by a distinct morphotectonic segmentation that follows the main NW-SE orientated fault zone (Hackney et al., 2006). The individual segments are showing a differentiated structural and geomorphological evolution (Rehak et al., 2008). The continental hinterland is characterized by three principal physiographic and morphotectonic units: the Coastal Cordillera, the Longitudinal Valley (Muñoz et al., 2000), and the Main Cordillera (Thornburg and Kulm, 1987). The Coastal Cordillera exposes moderate elevations generally below $500 \mathrm{~m}$ a.s.l. while the Main Cordillera reaches up to 2000-3000 m a.s.l. The Longitudinal Valley between both mountain ranges is filled with up to $4000 \mathrm{~m}$ thick Neogene to recent mainly alluvial sediments (Melnick and Echtler 2006b).

In the investigated area, the intermediate width of the Chilean continental shelf averages $20-30 \mathrm{~km}$, with the shelf edge lying in a water depth of maximal 150-250 m (Zapata, 2001). Large submarine canyon systems are crossing the westwards sloping margin in prolongation of major onshore river systems. These canyons are acting as natural sediment traps and channels for terrestrial sediments that are transported down the continental slope filling the Perú-Chile trench at about $4000 \mathrm{~m}$ water depth (Völker et al., 2006).

Several canyon systems can be distinguished within the study area; from south to north they are associated with the Valdivia, Toltén, Imperial, and Bío Bío River systems (Fig. 2). Most of these canyons are building up submarine fans where they enter the trench. The outer limit of these fans is marked by a slightly winding axial channel of 1 to $5 \mathrm{~km}$ width and 50 to $200 \mathrm{~m}$ depth (Völker et al., 2006), which takes course northwards within the trench for more than $1000 \mathrm{~km}$. The 


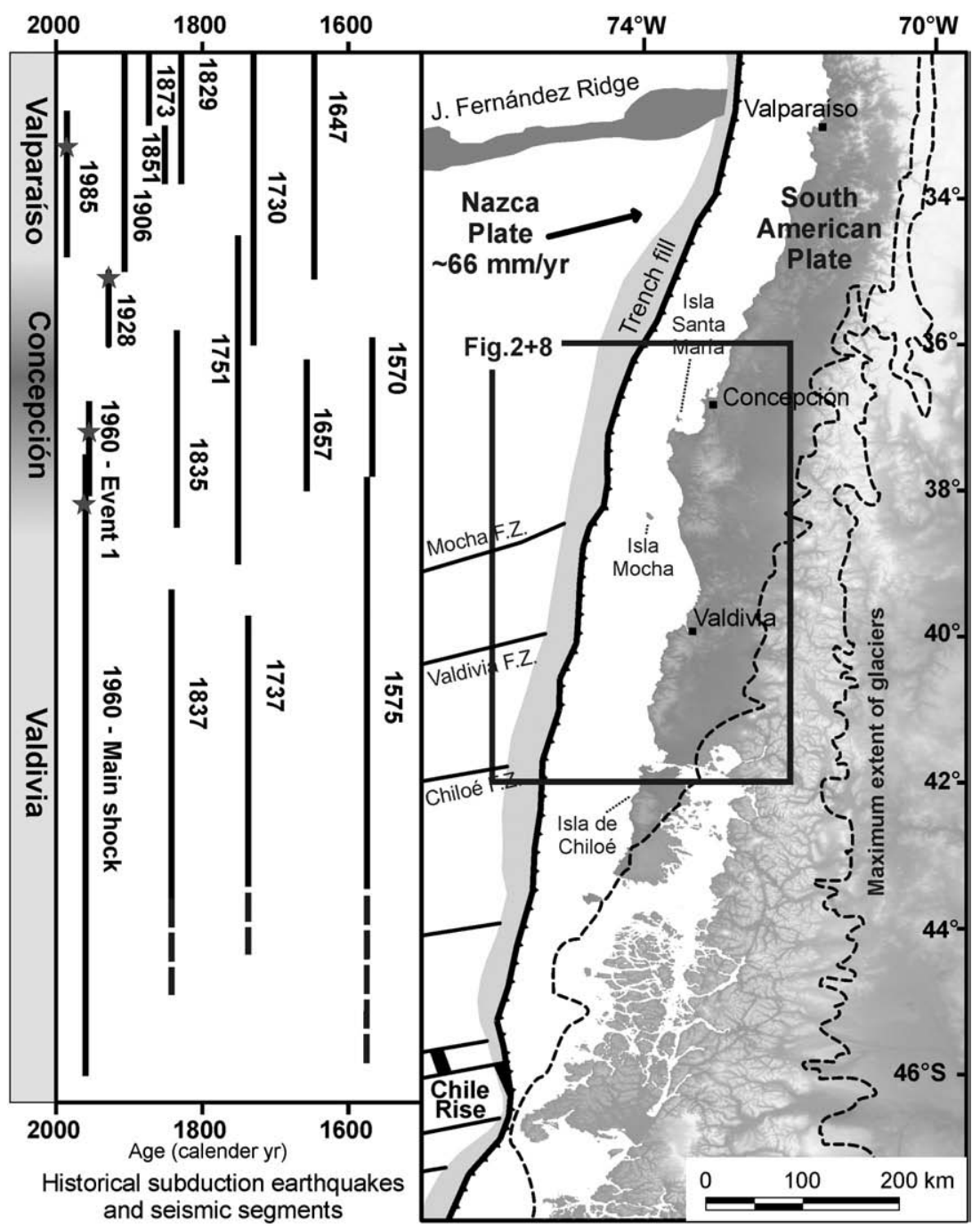

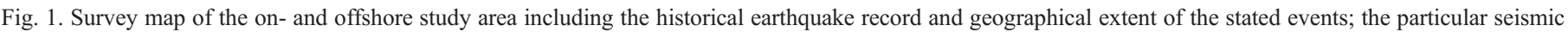

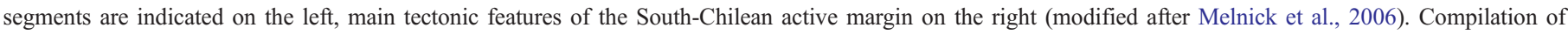

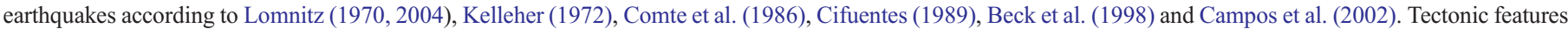

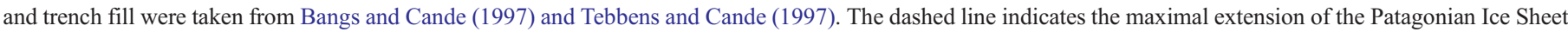
during the Last Glacial (after Rabassa and Clapperton, 1990). F.Z.=fracture zone.

channel is part of the collective depositional trench system in which the sediments are generally transported equatorwards due to a slightly northward tilting of the northward older and in consequence colder and less buoyant oceanic plate (Thornburg and Kulm, 1987; Thornburg et al., 1990). The Juan-Fernández ridge $\left(33^{\circ} \mathrm{S}\right)$ forms a natural barrier to these mass flows (Melnick and Echtler 2006a).

\subsection{Present and past climate}

Today, the study area is located within the transition zone between a summer dry Mediterranean climate north of $37^{\circ} \mathrm{S}$ and year-round humid conditions south of $42^{\circ} \mathrm{S}$. The local climate is characterized by humid temperate conditions with all-season precipitation peaking in austral winter (Miller, 1976). Prevalent cyclonic storms originating from the Southern Westerlies are bringing heavy rainfalls to the coastal mountains and the Andes $\left(\sim 2500 \mathrm{~mm} / \mathrm{yr}\right.$ at $\left.40^{\circ} \mathrm{S}\right)$. As a consequence, local erosion rates are high and induce enormous fluvial sediment fluxes to the ocean (Lamy et al., 2001). The track and intensity of the prevailing storms is generally regulated by the strength and position of the subtropical anticyclone in the Southeast Pacific and by the circum-Antarctic low pressure belt (Markgraf, 1998). The persistent blowing westerly winds prevent coastal upwelling south of $39^{\circ} \mathrm{S}$ (Mohtadi et al., 2005).

Studies of terrestrial and marine paleoclimatic records demonstrate that the overall rainfall pattern and oceanographic regime shifted by $\sim 5^{\circ}$ of latitude between glacials and interglacials (Veit, 1996; Lamy et al., 2001). Apparently, this shift is due to a northward displacement of the Antarctic Circumpolar Current and the associated Southern Westerlies under glacial conditions (Lamy et al., 2004). Compared to the Holocene, the local continental precipitation was remarkably high during the last glacial period. At the same time, southern 


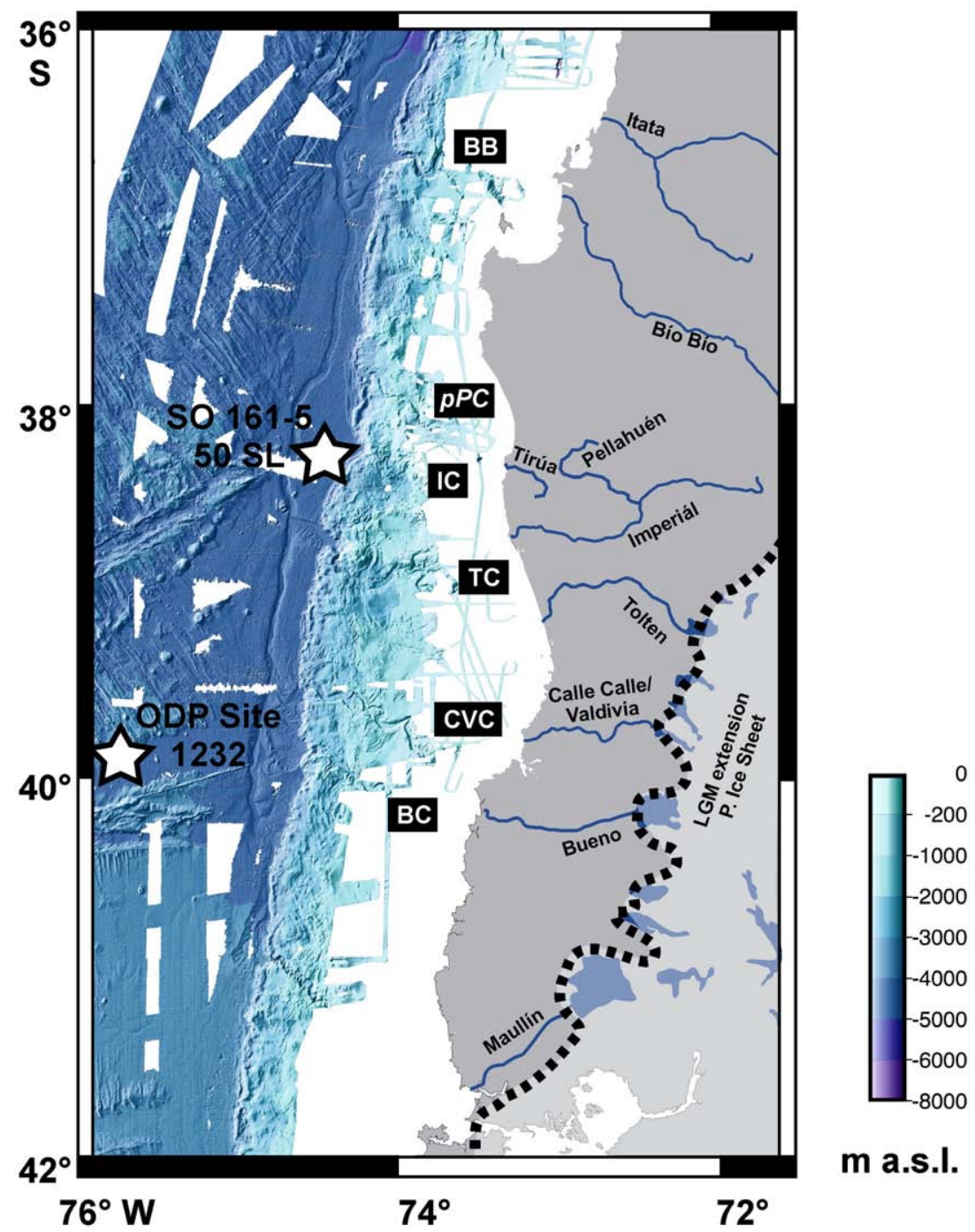

Fig. 2. Local bathymetry (modified after Grevemeyer et al., 2005; Völker et al., 2006), courses of rivers and corresponding canyon systems (canyon systems according to Thornburg et al., 1990). BC=Bío Canyon, pPC=paleo Pellahuén Canyon, IC $=$ Imperial Canyon, TC $=$ Toltén Canyon, CVC $=$ Calle Calle/Valdivia Canyon, $\mathrm{BC}=$ Bueno Canyon. Core locations of both investigated sediment cores are plotted.

Chile was covered by the Patagonian Ice Sheet, which stretched out $\sim 1800 \mathrm{~km}$ along the axis of the Andes (between $\sim 38^{\circ}$ and $56^{\circ} \mathrm{S}$ ) during the Last Glacial Maximum (Fig. 1).

\section{Materials and methods}

The present study is based on marine sediments that were recovered in the Chile Basin at ODP Site 1232 during Leg 202 (Mix et al., 2003). The Site is located at the outer rim of the Perú-Chile trench, $\sim 85 \mathrm{~km}$ west of the continental slope $\left(39^{\circ} 53.45^{\prime} \mathrm{S}, 75^{\circ} 54.08^{\prime} \mathrm{W}\right)$ in a water depth of $4072 \mathrm{~m}$ (Fig. 2). Three Advanced Piston Corer holes were drilled to ensure a complete stratigraphic record. The recovered sediments extended to $362.1 \mathrm{~m}$ below sea floor (mbsf), and a composite section of 381.7 mcd (meter composite depth) was constructed.

The dominant lithology of the sequence is composed of greenish-gray to light-gray hemipelagic silty clay, displaying little visual variability and showing very few sedimentary struc- tures (Mix et al., 2003). Some mottling, light brown nodules and thin silt layers are occurring sporadically. The sand content is negligible; the silt content is varying between $\sim 10 \%$ and $40 \%$. Clay minerals and feldspars are abundant whereas amphiboles, pyroxenes, and quartz are present in minor amounts. Biogenic components are generally sparse.

A second lithology is intercalated with the dominant hemipelagic silty clay on decimeter scale (Mix et al., 2003). It consists of coarser and much darker material - typically silty sand or sandy silt - that strongly differs from the hemipelagic sediments in texture and physical properties, although not in mineralogy. In general, the coarser layers are overlying sharp, partly erosional basal contacts and grading upward over several centimeters to silty clay. They are interpreted as basal parts of distal turbidite deposits.

In the present study, we focus on the uppermost $100 \mathrm{mcd}$ of the sedimentary sequence because the deeper part of the core is strongly influenced by coring disturbance (Mix et al., 2003). The alternation of hemipelagic clays and coarser turbiditic 
deposits is also typical for gravity core 50SL that was recovered during SONNE cruise 161-5 on top of an unnamed seamount that rises $200 \mathrm{~m}$ from the surrounding flat, sediment-filled floor of the Perú-Chile trench (Wiedicke-Hombach et al., 2002). The $732 \mathrm{~cm}$ long core is located north of ODP Site 1232 at $38^{\circ} 18.75^{\prime} \mathrm{S}, 74^{\circ} 41.85^{\prime} \mathrm{W}$ in a water depth of $4380 \mathrm{~m}, 15 \mathrm{~km}$ west of the Chilean continental slope (Fig. 2).

\subsection{Turbidite identification}

Turbiditic layers of ODP Site 1232 were identified by means of their physical properties like magnetic susceptibility and color, as these proxies show characteristic differences between the turbidites and hemipelagic background sediments (Fig. 3).

Whole core magnetic susceptibility measurements were collected on board the drilling vessel JOIDES Resolution at 5-cm increments with the ODP multisensor track (Mix et al., 2003). This relatively low resolution did not allow the detection of each single turbidite layer. A more precise identification of turbidites was attained by a detailed description of the split core and by highresolution greyscale processing of digital core pictures. In this way, the core depth and the thickness of each turbiditic layer could be clearly identified. Afterwards, all turbidites were subtracted from the record, in order to correct the depth for stratigraphic

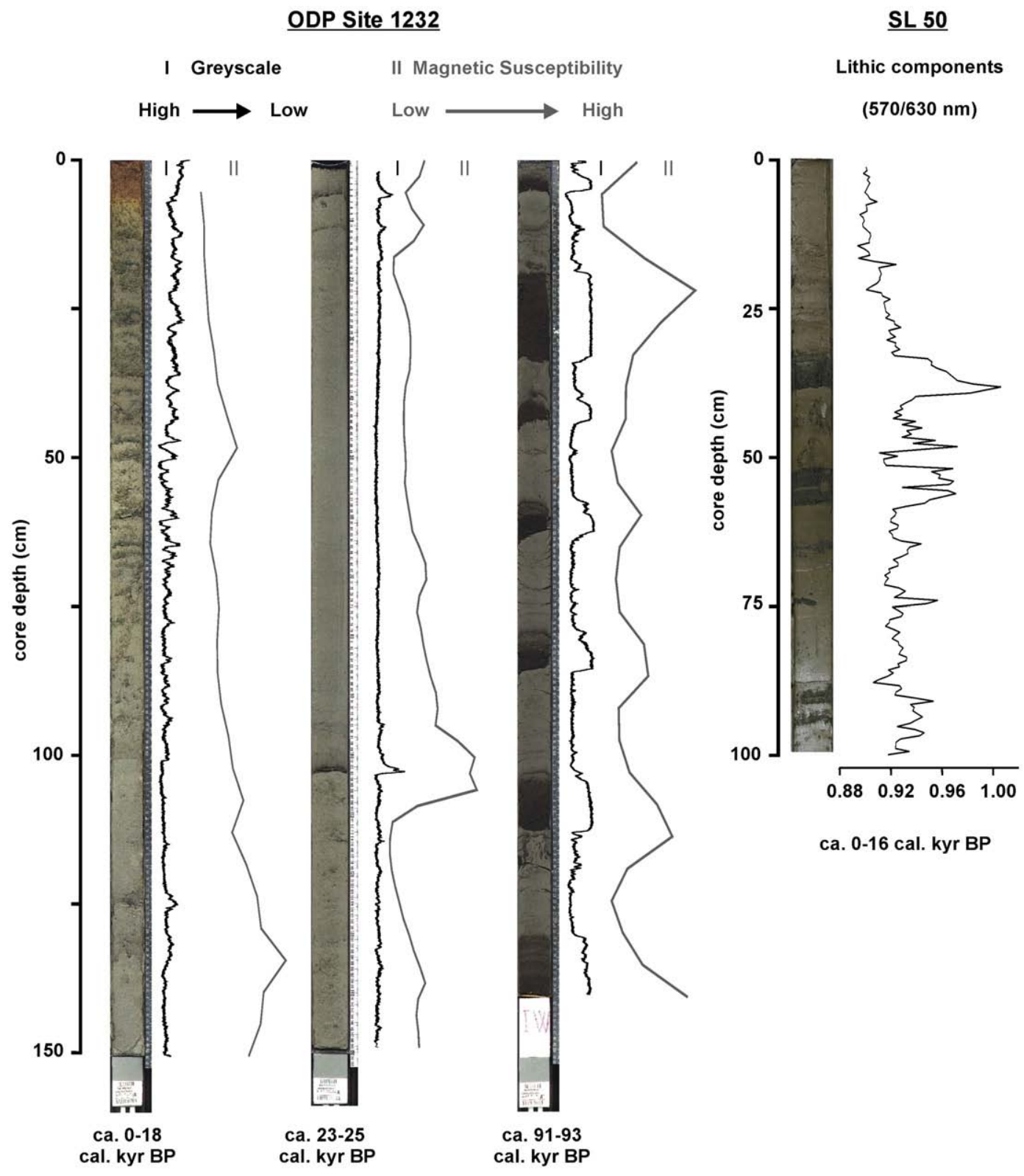

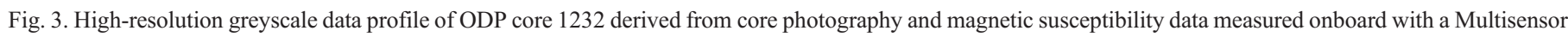

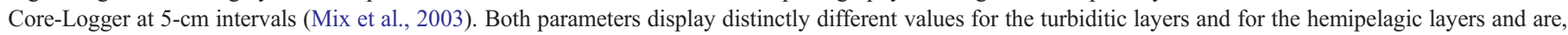

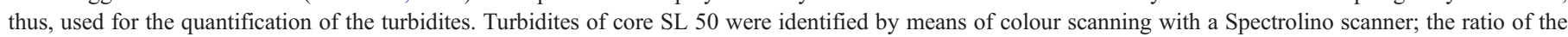
reflectance at $570 \mathrm{~nm}$ over that of $630 \mathrm{~nm}$ provides a proxy for lithic sediment components (Rein \& Sirocko, 2001; Rein, 2003). 
purposes, considering only the undisturbed hemipelagic sediments. In the following, all corrected depth information of ODP Site 1232 is given in meter corrected composite depth (mccd).

Turbidites in RV SONNE core 50SL (SO161) were initially identified by core logging with a GEOTEK core logger using a gamma attenuation probe; logging interval was $2 \mathrm{~cm}$. A refinement of the results was achieved by core description of the split and opened core and subsequent high-resolution colour scanning with the Spectrolino scanner of GRETAG; scanning interval was $5 \mathrm{~mm}$. This instrument acquires reflectance spectra of visible light in 36 discrete wavelength intervals between 380 and $730 \mathrm{~nm}$. According to Rein and Sirocko (2001) and Rein (2003) a simple ratio of the reflectance at $570 \mathrm{~nm}$ over that of $630 \mathrm{~nm}$ provides a proxy for lithic sediment components (Fig. 3). Consistent with ODP Site 1232, the identified turbidites of core 50SL were subtracted from the original record for depth correction.

\subsection{Stratigraphy}

A preliminary age model for ODP Site 1232 was created on board the vessel, based on biostratigraphic and paleomagnetic data (Mix et al., 2003). We updated and improved this model by using ${ }^{14} \mathrm{C}$ accelerator mass spectrometry (AMS) dating and stable oxygen isotope measurements on planktonic foraminifera (Globigerina bulloides). Samples for dating and stable isotope measurements were extracted from the hemipelagic sediments just beneath the turbiditic sequences. Sample spacing was about

Table 1

AMS ${ }^{14} \mathrm{C}$ ages of ODP Site 1232 and correlation points to oxygen isotope data of core MD 97-2120 from the south-western Pacific (Pahnke et al., 2003)

\begin{tabular}{|c|c|c|c|c|c|}
\hline $\begin{array}{l}\text { Orig. } \\
\text { depth } \\
\text { (mcd) }\end{array}$ & $\begin{array}{l}\text { Corr. } \\
\text { depth } \\
\text { (mccd) }\end{array}$ & $\begin{array}{l}{ }^{14} \mathrm{C} \text { AMS } \\
\text { age } \\
(\mathrm{kyr})\end{array}$ & $\begin{array}{l}\text { Calibrated } \\
\text { age } \\
\text { (kyr cal. B.P.) }\end{array}$ & $\begin{array}{l}\text { Dating } \\
\text { method }\end{array}$ & $\begin{array}{l}\text { Dated } \\
\text { material }\end{array}$ \\
\hline 0.6 & 0.35 & - & 12.47 & $\begin{array}{l}\text { Correlation to } \\
\text { MD } 97-210\end{array}$ & G. bulloides \\
\hline 0.8 & 0.48 & $15.31 \pm 0.07$ & $18.04 \pm 0.33$ & $\begin{array}{l}{ }^{14} \mathrm{C} \text { AMS } \\
\text { (KIA 27368) }\end{array}$ & $\begin{array}{l}\text { Mixed } \\
\text { planktonic }\end{array}$ \\
\hline 3.69 & 2.99 & $17.83 \pm 0.09$ & $20.53 \pm 0.34$ & $\begin{array}{l}{ }^{14} \text { C AMS } \\
\text { (KIA 27369) }\end{array}$ & $\begin{array}{l}\text { Mixed } \\
\text { planktonic }\end{array}$ \\
\hline 6 & 4.76 & $20.14 \pm 0.11$ & $23.03 \pm 0.18$ & $\begin{array}{l}{ }^{14} \mathrm{C} \text { AMS } \\
(\text { KIA } 27370)\end{array}$ & $\begin{array}{l}\text { Mixed } \\
\text { planktonic }\end{array}$ \\
\hline 14.64 & 11.66 & $25.25 \pm 0.21$ & $28.82 \pm 0.29$ & $\begin{array}{l}{ }^{14} \mathrm{C} \text { AMS } \\
(\text { KIA 27371) }\end{array}$ & $\begin{array}{l}\text { Mixed } \\
\text { planktonic }\end{array}$ \\
\hline 23.74 & 17.55 & $30.47 \pm 0.37$ & $34.34 \pm 0.43$ & $\begin{array}{l}{ }^{14} \text { C AMS } \\
\text { (KIA 27372) }\end{array}$ & $\begin{array}{l}\text { Mixed } \\
\text { planktonic }\end{array}$ \\
\hline 34.14 & 23.18 & $43.09 \pm 1.7$ & $44.24 \pm 1.29$ & $\begin{array}{l}{ }^{14} \mathrm{C} \text { AMS } \\
\text { (KIA 27373) }\end{array}$ & $\begin{array}{l}\text { Mixed } \\
\text { planktonic }\end{array}$ \\
\hline 48.36 & 32.07 & - & 66.09 & $\begin{array}{l}\text { Correlation to } \\
\text { MD 97-2120 }\end{array}$ & G. bulloides \\
\hline 81.68 & 53.98 & - & 113.58 & $\begin{array}{l}\text { Correlation to } \\
\text { MD 97-2120 }\end{array}$ & G. bulloides \\
\hline 91.93 & 60.23 & - & 120.21 & $\begin{array}{l}\text { Correlation to } \\
\text { MD 97-2120 }\end{array}$ & G. bulloides \\
\hline 92.64 & 60.69 & - & 129.25 & $\begin{array}{l}\text { Correlation to } \\
\text { MD } 97-2120\end{array}$ & G. bulloides \\
\hline 96.8 & 64.26 & - & 138.16 & $\begin{array}{l}\text { Correlation to } \\
\text { MD 97-2120 }\end{array}$ & G. bulloides \\
\hline
\end{tabular}

Table 2

AMS ${ }^{14} \mathrm{C}$ ages of SONNE core 50SL and correlation points to oxygen isotope data of core MD 97-2120 from the south-western Pacific (Pahnke et al., 2003)

\begin{tabular}{|c|c|c|c|c|c|}
\hline $\begin{array}{l}\text { Orig. } \\
\text { depth } \\
(\mathrm{m})\end{array}$ & $\begin{array}{l}\text { Corr. } \\
\text { depth } \\
\text { (m) }\end{array}$ & $\begin{array}{l}{ }^{14} \mathrm{C} \text { AMS } \\
\text { age } \\
(\mathrm{kyr})\end{array}$ & $\begin{array}{l}\text { Calibrated } \\
\text { age } \\
\text { (kyr cal. B.P.) }\end{array}$ & $\begin{array}{l}\text { Dating } \\
\text { method }\end{array}$ & $\begin{array}{l}\text { Dated } \\
\text { material }\end{array}$ \\
\hline $0.1-0.25$ & $0.1-0.25$ & $2.58 \pm 0.035$ & $2.21 \pm 0.08$ & $\begin{array}{l}{ }^{14} \text { C AMS } \\
\text { (KIA 21757) }\end{array}$ & $\begin{array}{l}\text { Mixed } \\
\text { planktonic }\end{array}$ \\
\hline 1.05 & 0.82 & - & 15.24 & $\begin{array}{l}\text { Correlation to } \\
\text { MD 97-2120 }\end{array}$ & G. bulloides \\
\hline 1.26 & 1.01 & - & 17.54 & $\begin{array}{l}\text { Correlation to } \\
\text { MD 97-2120 }\end{array}$ & G. bulloides \\
\hline $1.45-1.60$ & $1.18-1.33$ & $15.25 \pm 0.09$ & $18.0 \pm 0.35$ & $\begin{array}{l}{ }^{14} \text { C AMS } \\
\text { (KIA 21758) }\end{array}$ & $\begin{array}{l}\text { Mixed } \\
\text { planktonic }\end{array}$ \\
\hline $4.0-4.15$ & $3.06-3.21$ & $17.38 \pm 0.1$ & $19.9 \pm 0.18$ & $\begin{array}{l}{ }^{14} \mathrm{C} \text { AMS } \\
\text { (KIA 25258) }\end{array}$ & $\begin{array}{l}\text { Mixed } \\
\text { planktonic }\end{array}$ \\
\hline $6.10-6.20$ & $4.41-4.51$ & $19.16 \pm 0.12$ & $22.08 \pm 0.45$ & $\begin{array}{l}{ }^{14} \text { C AMS } \\
\text { (KIA 25259) }\end{array}$ & $\begin{array}{l}\text { Mixed } \\
\text { planktonic }\end{array}$ \\
\hline 7.26 & 5.42 & - & 23.25 & $\begin{array}{l}\text { Correlation to } \\
\text { MD 97-2120 }\end{array}$ & G. bulloides \\
\hline
\end{tabular}

$30 \mathrm{~cm}$. The resolution of our isotope record is lower for the MIS 5 , as carbonate content is very low and many samples did not contain sufficient foraminifera.

Absolute age control for the interval between 0.8 and 34.14 mced is provided by six AMS ${ }^{14} \mathrm{C}$-dates on mixed planktonic foraminifera samples, which were analysed at the Leibniz Laboratory in Kiel (Table 1). We calibrated the ages with the CALPAL software, using the CALPAL 2004 January calibration curve (Stuiver et al., 1998; Hughen et al., 2004). We presume no regional variation from the global reservoir effect of 400 years because the site is situated distinctly south of the Chilean upwelling zone and well north of the southern polar front. This corresponds to the mean reservoir effect for the Pacific Ocean of 400 years (Lamy et al., 2004).

Age control below 34.14 mccd is provided by the correlation of the oxygen isotope data of ODP Site 1232 and the well dated oxygen isotope record of core MD 97-2120 from the southwestern Pacific (Pahnke et al., 2003) (Table 1). Stable oxygen isotope measurements of both records are based on the planktonic foraminifera $G$. bulloides. The oxygen isotopes of ODP Site 1232 were analysed at the GFZ Potsdam, using a Finnigan MAT 253 mass spectrometer coupled with an automatic carbonate preparation system (Kiel IV device). To prevent a size-dependent effect on the $\delta^{18} \mathrm{O}$ values and to reduce a possible intrasample noise, ten foraminifera with a diameter of 250-350 $\mu \mathrm{m}$ were hand-picked per sample and used for the measurements. The ${ }^{18} \mathrm{O} /{ }^{16} \mathrm{O}$ ratio is given in delta notation and per mil (\%o) relative to the VPDB standard calibrated with NBS-19. Analytical standard deviation for $\delta^{18} \mathrm{O}$ is less than $0.06 \%$.

Similarly, stable oxygen isotope analyses of SONNE core 50SL were established using the planktonic foraminifera G. bulloides; a general stratigraphy is presented in Völker et al. (2006). In accordance with the age model generation of ODP Site 1232, we also correlated the oxygen isotope data of core 50SL to the oxygen isotope record of core MD 97-2120 (Table 2). 
For absolute age control of core 50SL four AMS ${ }^{14} \mathrm{C}$ mixed planktonic foraminiferal samples were extracted from $15 \mathrm{~cm}$ depth-sections of the core (Table 2). Analyses were done at the Leibniz Laboratory in Kiel. All ages were calibrated as described above.

\section{Results}

\subsection{Turbidites}

In total, more than 600 turbiditic layers were identified within the uppermost 100 mcd of the Site 1232 sedimentary sequence using the combined macroscopic and colour scan identification. All of them show a characteristic sharp, although rarely planar, basal contact. Many of the contacts have a potential erosional surface and/or are deformed and inclined from parallel to nearly perpendicular to the overall layering, perhaps as a result of drilling disturbances (Mix et al., 2003). Internally, the turbiditic layers show the typical grading upward. In many cases the upper limit of the layers is blurred and poorly defined; it is then difficult to exactly determine the boundary between the turbiditic layers and the new start of the hemipelagic sedimentation. However, measured from the basal contact to the first clear shift in colour and magnetic susceptibility, the turbidite thicknesses vary between few millimeters and several decimeters, with an average of $\sim 5 \mathrm{~cm}$ (Fig. 3). The total thickness of all turbiditic layers adds up to more than $30 \mathrm{~m}$ ( $>30 \%$ of the whole section), which leaves $\sim 70 \mathrm{~m}$ of undisturbed hemipelagic sediments $(\sim 70 \%$ of the whole section).

A total of 47 turbiditic layers were identified in SONNE core 50SL. Turbidites vary in thickness between about $5 \mathrm{~mm}$ and $\sim 11 \mathrm{~cm}$ with an average of $\sim 3.9 \mathrm{~cm}$. The layers display sharp to diffuse (bioturbation) lower boundaries and commonly well developed upward fining (Wiedicke-Hombach et al., 2002). Several turbidites show multiple sedimentation pulses, which in some cases complicate proper turbidite counting. As it is furthermore difficult to accurately identify the upper boundary of the turbiditic layers, a potential underestimation of their thicknesses should be considered. The cumulative thickness of the turbiditic layers is $184 \mathrm{~cm}$, which is $25 \%$ of the considered core interval.

\subsection{Stratigraphy and sedimentation rates}

According to our stratigraphy, the investigated section of ODP Site 1232 has a basal age of $\sim 140 \mathrm{kyr} \mathrm{BP}$ and is covering one complete glacial/interglacial cycle (Fig. 4A). Unfortunately, no ${ }^{14} \mathrm{C}$-datings were possible for the Holocene and very few correlation points were available for MIS 5, because only few foraminifera were recovered in these stratigraphic intervals.

Over the entire $140 \mathrm{kyr}$, the mean sedimentation rate of the hemipelagic background sediments, excluding the turbidites, accounts for $\sim 0.5 \mathrm{~m} / \mathrm{kyr}$ (Fig. $4 \mathrm{~A}$ ). During Termination I and the Holocene, as well as during Termination II and the early MIS 5.5 , the sedimentation rate is distinctly reduced, down to values
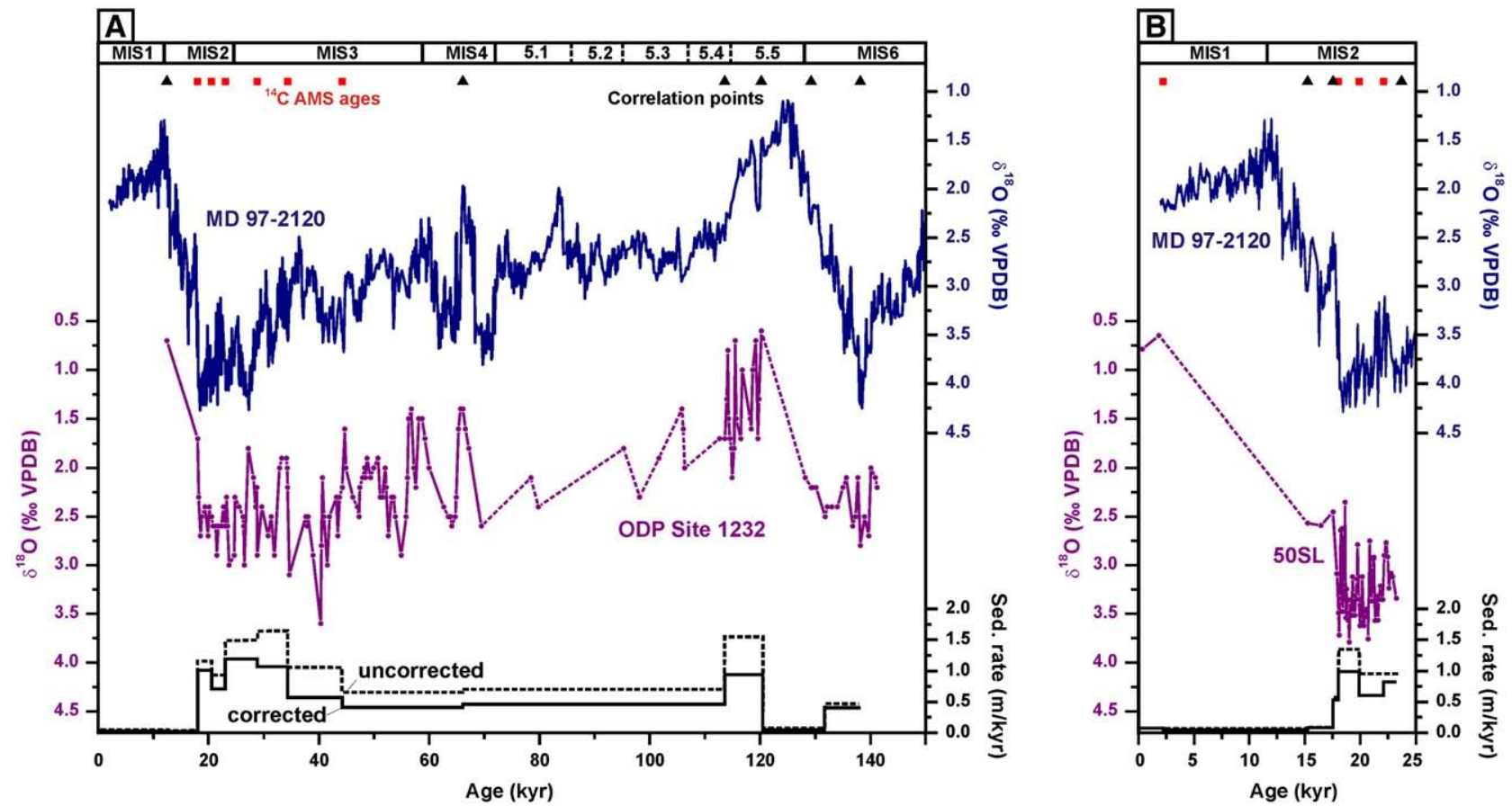

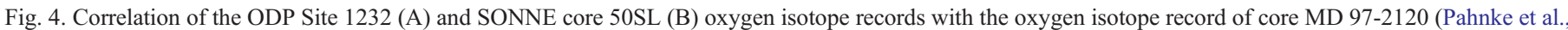

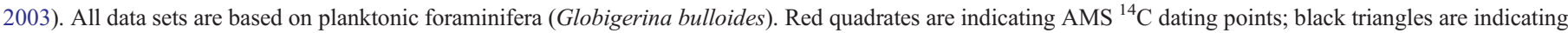

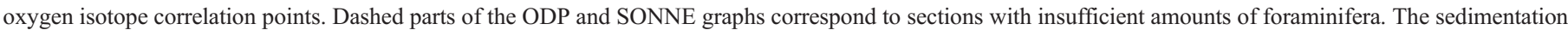

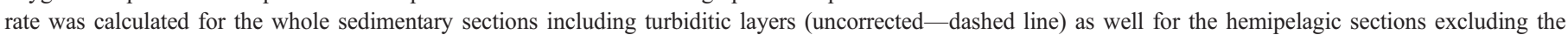
turbidites (corrected-solid line). (For interpretation of the references to colour in this figure legend, the reader is referred to the web version of this article.) 
of less than $0.1 \mathrm{~m} / \mathrm{kyr}$. That way, the complete Holocene unit, for example, is less than $80 \mathrm{~cm}$. Values of $1 \mathrm{~m} / \mathrm{kyr}$ or more are found during the Last Glacial and the late MIS 5.5. The most pronounced reduction of the sedimentation rate is taking place at approximately $18 \mathrm{kyr}$ BP. The uncorrected sedimentation rate, including also the turbiditic layers, is close to the hemipelagic sedimentation rate during the Holocene and early MIS 5.5, and about $40 \%$ higher for the remaining parts of the record.

SONNE gravity core 50SL reaches back into the Last Glacial (Fig. 4B). The Holocene sedimentation rate is less than $0.1 \mathrm{~m} / \mathrm{kyr}$ which is one order of magnitude lower than the rate during the Pleistocene ( $\sim \mathrm{m} / \mathrm{kyr})$. Similar to ODP Site 1232, the most striking change in sedimentation rate takes place at approximately 18 kyr BP.

\subsection{Turbidite recurrence rate}

We calculated the recurrence times of the turbiditic layers on the base of the developed stratigraphy and compared their variations to changes of the global sea level curve for the investigated period. The time intervals between successive turbidite layers are distinctly longer for periods of high sea level than for those of low sea level.

In ODP Site 1232, the recurrence times of turbidites are consistently $\geq 1 \mathrm{kyr}$ for the Holocene, MIS 5.1, MIS 5.3, and MIS 5.5 (Fig. 5A). In contrast, during MIS 2, MIS 3, the cold substages of MIS 5, and MIS 6, the average recurrence times are between 100 and 200 years. Recurrence times of turbidites in SONNE core 50SL are likewise $\geq 1 \mathrm{kyr}$ during the Holocene and fluctuating around 200 years for the Last Glacial (Fig. 5B).

In addition, periods of high recurrence rates tend to display slightly thicker turbidites (Fig. 6): almost all turbiditic layers that were deposited during the interglacial periods are less than $5 \mathrm{~cm}$ thick, while numerous glacial turbidites reach a thickness of $\geq 20 \mathrm{~cm}$. Especially in the Holocene section, the turbidites are remarkably thin and difficult to identify.

All turbidite data (original and corrected depth, thickness, age and recurrence time) as well as the oxygen isotope data are
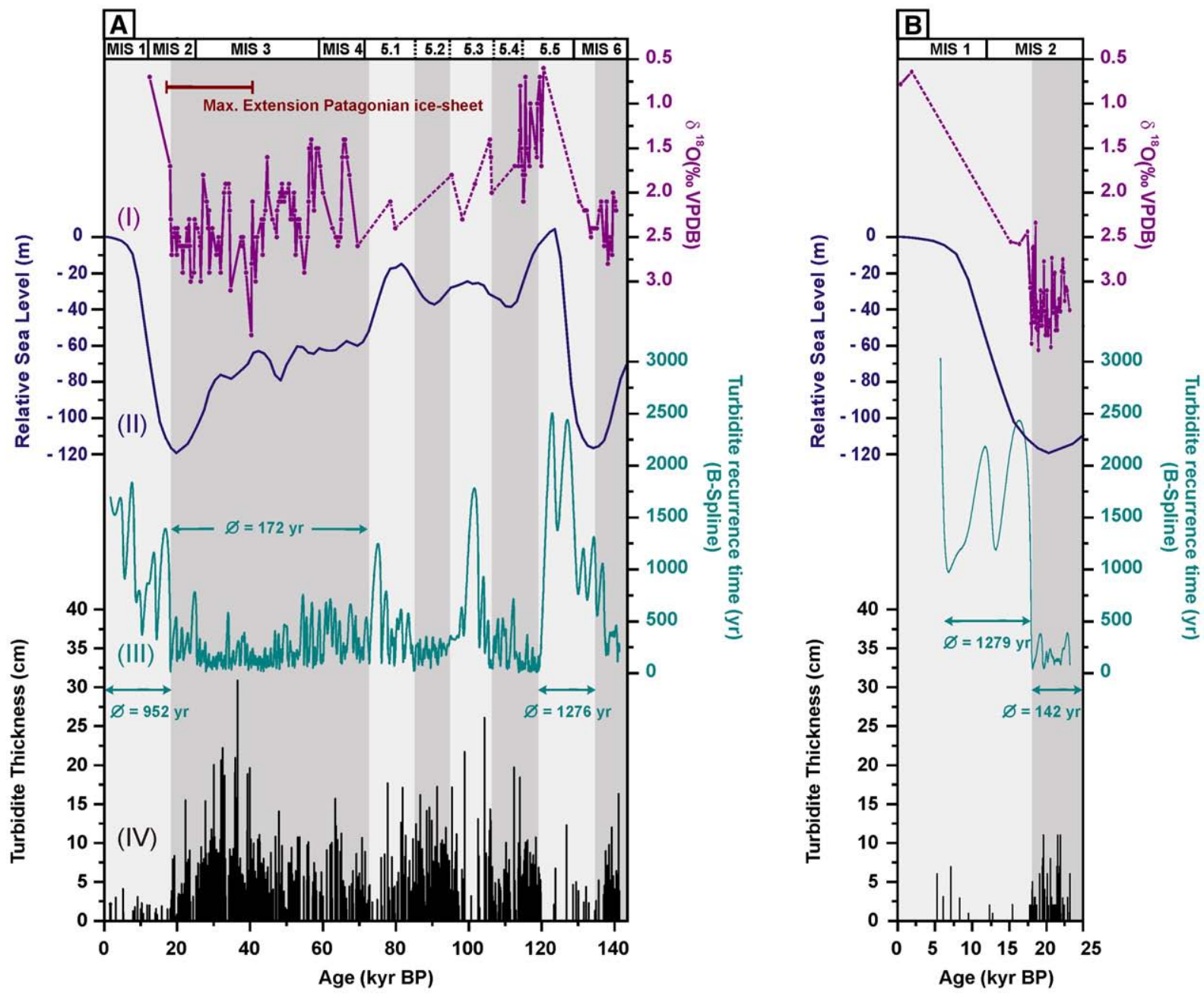

Fig. 5. Turbidite and oxygen isotope records of ODP Site 1232 (A) and SONNE core 50SL (B) compared to the global sea level record for the past 140 kyr. (I) Oxygen isotope record (\%)VPDB), (II) global sea level record (after Waelbroeck et al., 2002), (III) calculated turbidite recurrence time (kyr) displayed as B-Spline, (IV) thickness of turbiditic layers (cm). Light gray bars highlight episodes of long turbidite recurrence times during periods of sea level highstand and during terminations; darker gray bars highlight episodes of short turbidite recurrence times during periods of low sea level. The period of maximal Patagonian ice sheet extension is indicated by the brown bar at the top of the graph. (For interpretation of the references to colour in this figure legend, the reader is referred to the web version of this article.) 


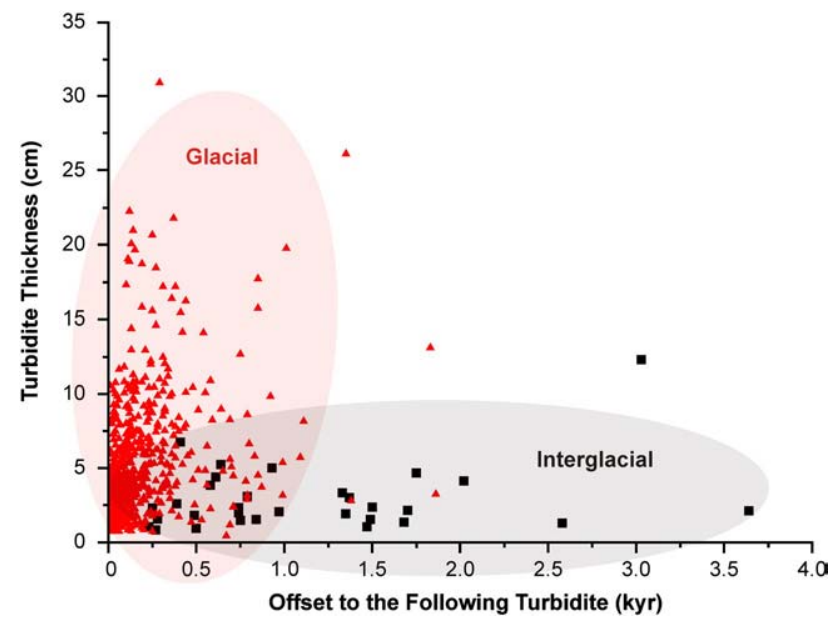

Fig. 6. Relation between the thickness of ODP Site 1232 turbidites $(\mathrm{cm})$ and the offset to the following turbiditic layer (kyr). Glacial periods are generally characterized by slightly thicker turbidites and shorter offsets than interglacial periods.

available in electronic Appendix A of this paper and under the name of the corresponding author through the PANGAEA server (www.pangaea.de).

\section{Discussion}

\subsection{Turbidite generation}

Einsele et al. (1996) showed that the generation of event deposits such as turbidites takes place in several phases and stressed the need for a pre-event phase of sufficient sediment accumulation. Thus, the composition and accumulation of the sediment in the source area - in our case the amount of sediments stored on the South-Chilean upper continental slope - is an important precondition for the generation of turbidites. Due to the humid climatic conditions and pronounced topographic gradients in the hinterland of the study area, the terrigenous sediment delivery to the continental shelf is at present mainly fluvial (Lamy et al., 2001). The sediments are mostly originating from the Main Cordillera and the western foreland as the high precipitation along the Andean barrier allows the rivers to cut through the Coastal Ranges and to transport their sediment load towards the continental slope (Stuut et al., 2007). The main regional sediment supply to ODP Site 1232 comes from the Calle Calle/Valdivia and Bueno Rivers, which originate at $\sim 40^{\circ} \mathrm{S}$ in the Chilean Lake district, and which channel the sediments through large hydrographical systems across the continental shelf into the deep sea trench (Fig. 2). Similarly, Rio Imperial and Rio Toltén are the main river agents that supply sedimentary material to the locality of SONNE core 50SL.

Ultimate trigger mechanisms for the periodically occurring depositional events could be great earthquakes, tsunamis, storm wave loading, or simply the dimension of the sediment loading (Mutti et al., 1984; Adams, 1990; Einsele et al., 1996). Depending amongst others on the trigger mechanism, the resulting turbidites will be varying in size. Due to their specific locations far from the continental slope and high above the trench surface, ODP core 1232 and SONNE core SL50 are likely non-ideal archives in regard to the registration of all occurring turbidites. Many events may be missing in the sedimentary record as their extent has been simply too small to reach the site positions. On this account, a) the long distance between ODP Site 1232 and the potential source area of turbidites, b) the elevated position of SONNE core SL50 high above the trench surface, and c) the nonetheless remarkable thicknesses of individual turbiditic layers, account for exceptionally large and geographically extended depositional events. As giant turbidites are rather triggered by earthquakes than by storms or other local mechanisms (Gorsline et al., 2000), and in view of the seismic activity in Southern Chile, it is thus very likely that the turbidites of ODP Site 1232 and SONNE core 50SL are, in general, earthquake-triggered. This interpretation is supported also by sedimentological observations: many of the identified turbiditic layers consist of multiple pulses rather than a single one; this is thought to be a distinct feature of seismically induced turbidites (Nakajima and Kanai, 2000; Shiki et al., 2000). However, sedimentological arguments are not considered to be definite reliable evidence for seismically triggered turbidites. A more plausible and indicator would be the synchrony of turbiditic flows in several submarine drainage systems (Goldfinger et al., 2003). Due to a lack of neighbouring records in the study area with individually dated turbidites, we cannot prove the synchrony of event layers off Southern Chile. However, the generally similar variations in turbidite recurrence times of ODP Site 1232 and core 50SL corroborate our approach, even though a precise age control of single events is not possible.

According to the previous points, the cyclicity in turbidite recurrence and thickness that is observed for both investigated records may be either due to changes in the accumulation of sediments in the source area or to changes in the turbidite trigger mechanism. The sediment supply to the source are of turbidites is likely affected by variations in climate. For instance, during the Late Pleistocene, glaciers covered part of the continental shelf south of $42^{\circ} \mathrm{S}$ (Fig. 1) and delivered large amounts of sediments to the Pacific Ocean. We suggest that this extraordinary sediment supply explains the particularly thick turbidite beds of the Pleistocene trench fill.

\subsection{Turbidite deposition and climate changes}

According to our stratigraphy, the sedimentary record of ODP Site 1232 contains one complete glacial cycle, while the shorter core 50SL reaches back into the Last Glacial (Fig. 4). This allows us to compare glacial and interglacial turbidite recurrence times and to detect possible variations in relation to climate changes. In general, the pattern of the turbidite recurrence time follows the pattern of the glacio-eustatic sea level change. Average time spacing between turbidites is low during sea level lowstands and distinctly higher during interglacials. This glacial/interglacial contrast is not unique to Southern Chile but seems to follow a global-scale pattern. A Holocene decline in the recurrence time of turbidites is, for 
example, described for the Cap Timiris Canyon off Mauritania (Wien et al., 2006), the Ulleung Basin in the Japan Sea (Lee et al., 1996) and in the Mediterranean Sea (Baraza et al., 1990). We therefore interpret the long-term glacial-interglacial pattern in our turbidite recurrence rates to be primarily modulated by global climate and associated eustatic sea level changes.

The extensive glaciation of the continental hinterland and enhanced precipitation result in increased terrestrial erosion and sediment supply to the Pacific Ocean. Coevally, the global sea level is at a minimum under glacial conditions and shelf areas are exposed to erosion during these periods (Fig. 7A). This is not only enhancing the anyway high terrestrial sedimentation rate but also reducing the sediment accumulation space on the shelf. As a result, the sediment transport to the shelf edge and to the slope basins is pronounced, leading to unstable slope conditions. The sea level drop may also reduce the hydrostatic pressure on the near-surface slope sediments, leading to the build-up of excess pore pressure within the sediment further lowering the slope stability (Lee et al., 1996). The risk of a slope failure is, therefore, highest during phases of sea level lowstand (Einsele, 1996). Although ODP Site 1232 is located $\sim 85 \mathrm{~km}$ west of the lowermost slope far from the terrestrial sediment source, the sedimentation rate is high during cold stages and, in particular, during the Last Glacial (Fig. 4A); these findings are also consistent with the SONNE core 50SL record (Fig. 4B) and previous local studies (Lamy et al., 1999; Hebbeln et al., 2007).

During periods of falling sea level, storm waves should also be considered as trigger for turbidity currents. As the maximum water depth of wave-induced effects is estimated to be 80-120 m (Lee and Edwards, 1986), no significant effects can be expected for the Holocene high stand. However, during the Last Glacial, with a maximum sea level drop of $\sim 120 \mathrm{~m}$, the shelf edge and upper slope were within the reach of storm waves and potentially vulnerable to storm-induced turbidites.

The interglacial scenario is characterized by a very limited Patagonian Ice Sheet and by lower precipitation (e.g. Lamy et al., 2004; Hebbeln et al., 2007). Consequently, the continental erosion, the sediment supply to the Pacific Ocean, and the sediment accumulation on the continental shelf are reduced. As a result of the high sea level, the trench becomes more distal to the shoreline and the source areas of sediments. The shelf is spaciously drowned and acts as a first order depositional centre for the fluvially delivered sediments (Fig. 7B). Furthermore, the higher water column above the sediments may exert a stabilizing effect. While the basins of the Finger Lakes in the Chilean Lake District and the Chilean Fjords to the south were being occupied by glaciers during the Last Glacial, they may represent additional onshore depocenters during the interglacial. South of $\sim 42^{\circ} \mathrm{S}$, glaciers reached the continental shelf during the LGM and likely supplied large amounts of sediment that have been transported northwards along the trench. Today, and most likely also during previous interglacials, the shelf is ice free, acting as a large sediment trap for eroded continental material. That way, less sediment reaches the outer continental shelf and the generation of turbidites is less likely.

Recapitulatory, slope conditions are more stable under a high sea level regime and many of the occurring earthquakes do not succeed to cause a slope failure. In contrast, slope conditions at
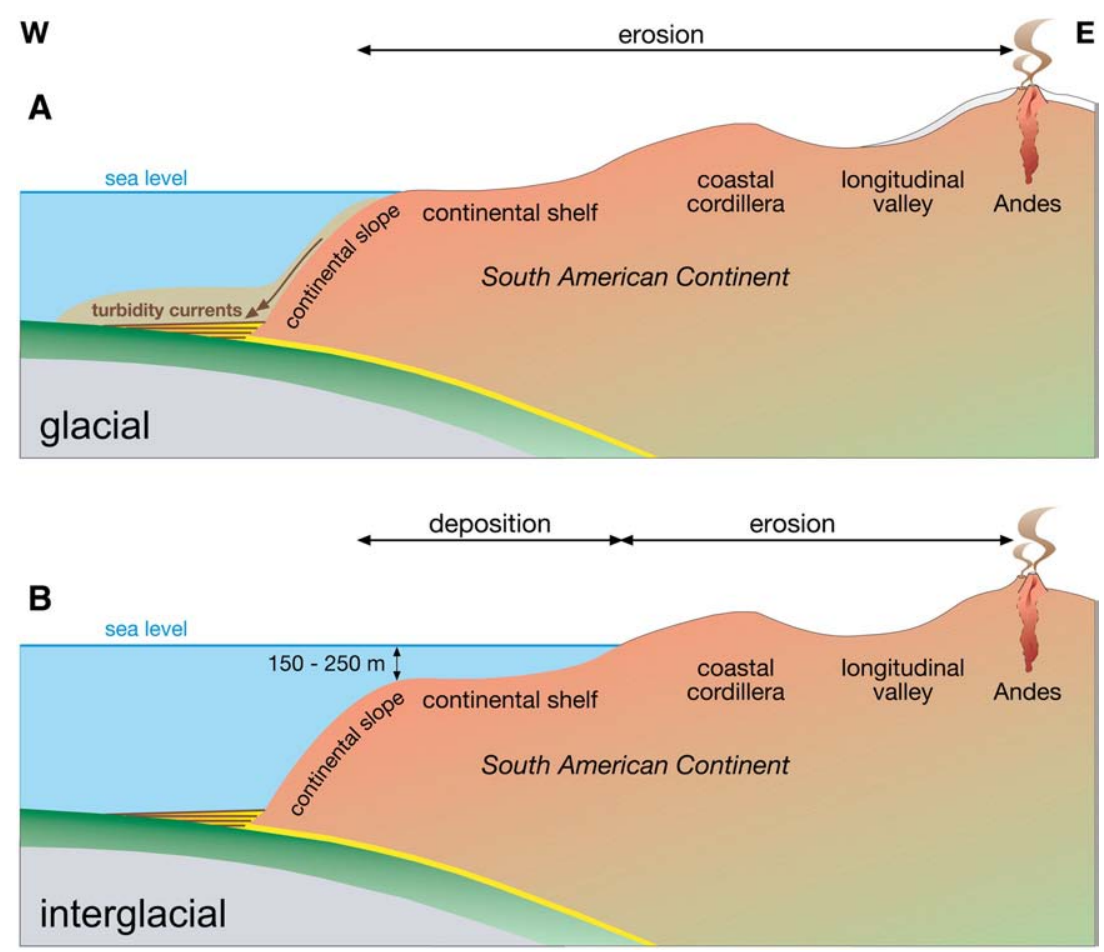

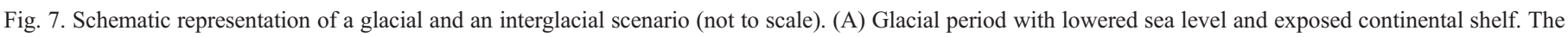

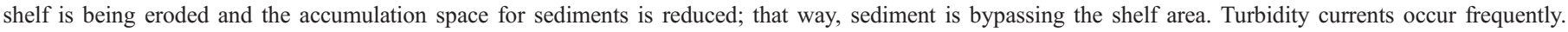

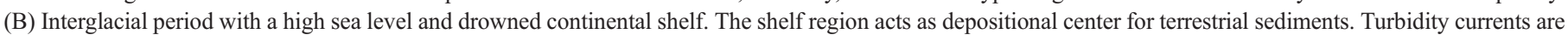
occurring sporadically. 
a low sea level period with high sedimentation rates are less stable and earthquakes are able to continuously generate submarine mass movements. We therefore consider the turbidite recurrence times of glacial periods to mainly reflect the recurrence times of earthquakes in the area.

\subsection{Turbidite deposition and earthquake recurrence times}

To evaluate whether the turbidite recurrence time can be considered as a useful proxy for the regional earthquake recurrence time, we compared our results with data of known paleoseismological archives in Southern Chile. The historical earthquake record for the Valdivia rupture zone contains megaearthquakes $(M \geq 8)$ and secondary effects in the years 1575 , 1737,1837 and 1960, resulting in an average recurrence interval of 128 years (Lomnitz, 1970, 2004) (Fig. 1). More recent interpretations of written historical documents closer differentiate between these single events, i.e. the 1575 and 1960 earthquakes were evidently greater than the effects of the 1737 and 1837 events (supplementary information of Cisternas et al., 2005). Based on these interpretations, the temporal distance between the two megaquakes of a similar strength in 1575 and 1960 is 385 years.

South of Valdivia, in the estuary of the river Maullín, Cisternas et al. (2005) investigated buried soils and sand layers as records of coseismic subsidence and tsunami flooding. These authors came up with an earthquake recurrence time of $\sim 285$ years for the last two millennia. Since not all earthquakes generate sufficient subsidence and/or tsunamis, these recurrence times may be somewhat long.

A study of coseismically uplifted beach berms on the Isla Santa María resulted in a much higher earthquake frequency of $180 \pm 65$ years for the last $3 \mathrm{kyr}$ (Bookhagen et al., 2006). However, the island is located on the Concepcion segment, neighbouring the Valdivia segment in the north. This indicates a difficulty in exactly correlating records of neighbouring segments and rupture zones that generated historic megaquakes do not necessarily correspond to single segments of the Chilean forearc but propagate well across segment boundaries (Melnick et al., 2006). The 1960 earthquake is a prominent example, as it originated close to the northern edge of the Valdivia rupture zone (Krawczyk and SPOC-Team, 2003) in the Nahuelbuta segment and propagated about $1000 \mathrm{~km}$ southward across the Toltén and Bueno segments.

When comparing our turbidite recurrence times with the values derived from the above cited Late Holocene earthquake records, two aspects should be considered: (a) our data cover a distinctly longer time period and (b) are considerably influenced by global climate changes. As a matter of fact, the Holocene turbidite recurrence times at ODP Site 1232 and SONNE core 50SL $(>1000 \mathrm{yr})$ seem to be inconsistent with the earthquake recurrence periods of the onshore paleoseismic archives (180-385 yr). However, during the glacial periods of sea level lowstands, the turbidite recurrence times $(\sim 100-290 \mathrm{yr})$ are fairly consistent with the onshore data. We therefore suggest that only during glacial periods, when the sediment availability and slope instability were high enough, all occurring earth- quakes triggered turbidites and left their marks in the sedimentary records. As during these periods other trigger mechanisms came into operation as well, the glacial earthquake recurrence times may be even overestimated.

\subsection{Turbidite deposition and fore-arc tectonics}

Along the active continental margin of Southern Chile, changes in turbidite thickness and frequency may not only be related to glacial-interglacial climate changes but also to particularities in the segmented fore-arc tectonics. In both records ODP Site 1232 and SONNE core 50SL, the most obvious decline in the turbidite recurrence time and thickness is taking place at the end of the Last Glacial, at $\sim 18 \mathrm{kyr}$ BP (Fig. 5). This frequency decline is certainly mainly controlled by climate changes, but we postulate a likely additional indirect

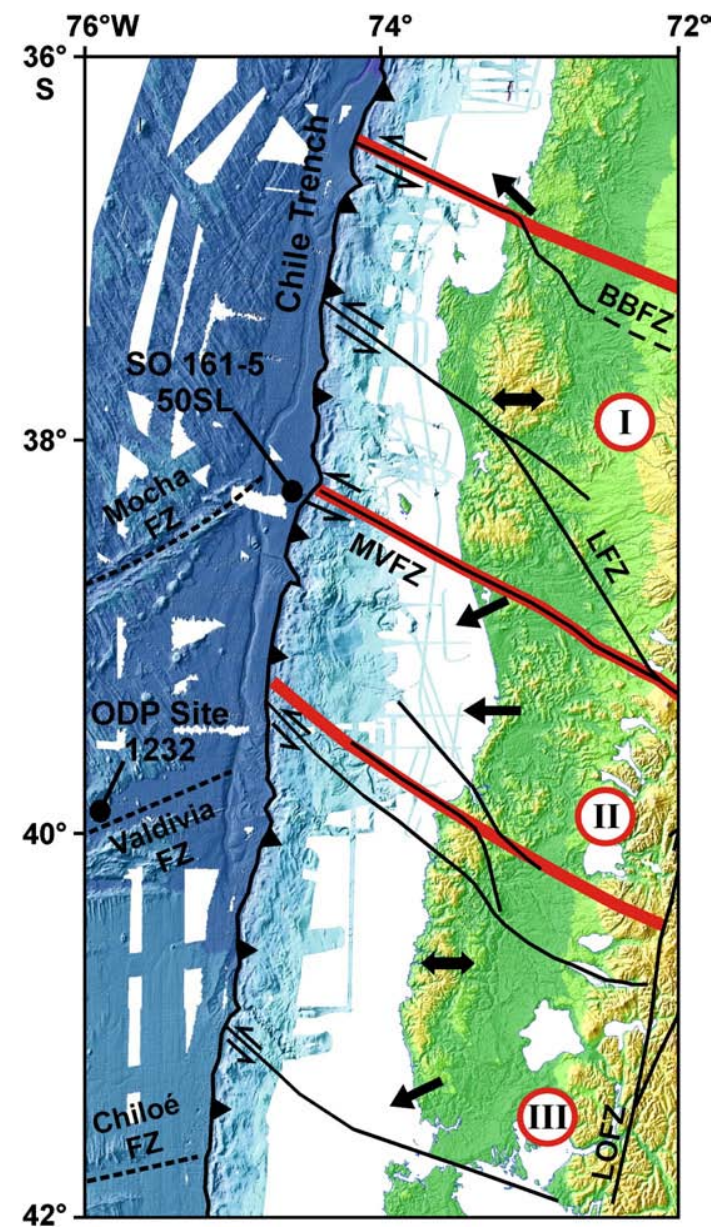

Fig. 8. Structural features and morphotectonic units of the study area (modified after Hackney et al., 2006; Rehak et al., 2008). Thick red lines separate the individual morphotectonic segments ( $\mathrm{I}=$ Nahuelbuta Segment, II=Toltén Segment, III=Bueno Segment). Thick black arrows indicate the present-day drainage pattern of the region with river flow inversions in the northern and southern segments and with a culmination of basin outlets in the low-relief Toltén Segment. Local topography and bathymetry modified after Grevemeyer et al. (2005) and Völker et al. (2006). FZ=Fracture Zone, BBFZ=Bío Bío Fault Zone, LFZ=Lanalhue Fault Zone (Glodny et al., in press), MVZ=MochaVillarica Fault Zone, LOFZ=Liquiñe-Ofqui Fault Zone. (For interpretation of the references to colour in this figure legend, the reader is referred to the web version of this article.) 
influence of tectonic uplift via influence on the on- and offshore sedimentation pattern.

Between $37^{\circ}$ and $41^{\circ} \mathrm{S}$, the Chilean forearc is divided into three morphotectonic segments that have undergone different subduction-related deformation during the Neogene (Hackney et al., 2006; Melnick and Echtler, 2006b) and Quaternary (Rehak et al., 2008) (Fig. 8). The central Toltén segment appears to be tectonically stable. The northern Nahuelbuta and the southern Bueno segment, however, are characterized by tectonically controlled drainage anomalies and rerouting of sediments by river flow inversions, indicating a steady uplift of both coastal regions (Rehak et al., 2008). Today, the most striking paleodrainage feature of the northern Nahuelbuta segment is the wind gap between the Pellahuén and Tirúa basin (Rehak et al., 2008) (Fig. 2). While Río Pellahuen formerly drained directly to the Pacific Ocean, it is at present crossing the Coastal Cordillera to the east. Its corresponding and previous active submarine canyon system is nowadays completely inactive due to the drainage inversion. That way the sediment supply to the deeper Ocean starved and, as a consequence, the generation of turbidites potentially diminished. In general, the drainage system of the southern Bueno segment indicates the same reorganization as the northern Nahuelbuta segment. The flow reversals are not precisely dated yet but would provide an explanation for the sudden drop in both the sedimentation rate and the turbidite frequency at $\sim 18$ kyr BP.

\section{Conclusions}

In this study, we analyse the recurrence time of turbidite layers in the marine sedimentary sequence of ODP Site 1232 and SONNE core 50SL off Southern Chile. In this active margin setting, we investigate the significance of trench deposits as paleoseismic archives. For the first time we examine a proxy record of $140 \mathrm{kyr}$ length, while previous similar studies focussed merely on the Late Holocene. The new long-time record reveals a glacial-interglacial change of turbidite recurrence times which seems to be related to global climate and sea level changes. The comparison of our record with different shorter onshore paleoseismic proxy records indicates that the turbidite recurrence times during glacial periods of low sea level are very similar to earthquake recurrence intervals found for the last three millennia.

There is much evidence that the climate is the driving factor of the long-term differences in the turbidite recurrence rates off Southern Chile by changing the sediment availability in the source area affecting the slope stability. Nevertheless, the change could be also more than a simple problem of sediment flux from the continent. It could be driven by a 'real' variation in the local earthquake recurrence rates, possibly induced by glacial load or postglacial isostatic rebound in the southern realm (ODP Site 1232), that could have influenced the coupling at the plate interface. More frequent mega-earthquakes during the glacial period could well explain the Holocene decline of turbidites in our record. However, as we do not know enough about the control and nature of turbidites triggered by differ- ential mechanisms (e.g. seismic, sea level, sediment flux), we have to leave this discussion open.

Turbiditic layers in sedimentary sequences are indirect records of paleoseismicity. Turbidite generation is highly depending on the amount and availability of sediment material and, in consequence, potentially affected by external factors such as climate and tectonics. Therefore, besides the need to verify earthquakes as trigger mechanism, it is also necessary to identify potential external factors which may obscure the use of turbidites as proxy for paleoseismicity, at least on glacialinterglacial time scales. Nevertheless, if these aspects are properly considered, our data emphasize that turbidite records of trench sequences at active margins with high sediment supply are valid archives of paleoseismology.

\section{Acknowledgements}

We thank T. Vietor and D. Melnick for helpful discussions and advices as well as B. Plessen for oxygen isotope measurements. Furthermore we, highly acknowledge the comments of two anonymous reviewers which improved the manuscript. The study was financially supported by the Helmholtz-funded Center for System Analysis of Geoprocesses (CSAG). This research used data and samples provided by the Ocean Drilling Program (ODP). The ODP is sponsored by the U.S. National Science Foundation (NSF) and participating countries under management of Joint Oceanographic Institutions (JOI), Inc.

Much of the analyses of the SONNE core 50SL (SO161-5) were done by T. Reichel within the TIPTEQ project (from the Incoming Plate to Megathrust Earthquakes) TP-L, funded by the German Ministry for Education and Research (BMBF) and the German Research Foundation (DFG) in the framework of the R\&D-Program GEOTECHNOLOGIEN "Continental Margins" (Grant 03G0594A). This is publication GEOTECH-283.

\section{Appendix A. Supplementary data}

Supplementary data associated with this article can be found, in the online version, at 10.1016/j.epsl.2008.02.007.

\section{References}

Adams, J., 1990. Paleoseismicity of the Cascadia Subduction Zone: evidence from turbidites off the Oregon-Washington Margin. Tectonics 9, 569-583.

Adams, J., 1996. Great earthquakes recorded by turbidites off the OregonWashington Coast. USGS Professional Paper 1560 (1), 147-158.

Angermann, D., Klotz, J., Reigber, C., 1999. Space-geodetic estimation of the Nazca-South America Euler vector. Earth Planet. Sci. Lett. 171 (3), 329.

Bangs, N., Cande, S.C., 1997. Episodic development of a convergent margin inferred from structures and processes along the southern Chile margin. Tectonics 16, 489-503.

Baraza, J., Lee, H.J., Kayen, R.E., Hampton, M.A., 1990. Geotechnical characteristics and slope stability on the Ebro margin, western Mediterranean. Mar. Geol. 95 (3-4), 379.

Beck, S., Barrientos, S., Kausel, E., Reyes, M., 1998. Source characteristics of historic earthquakes along the Central Chile subduction zone. J. South Am. Earth Sci. 11, 115-129.

Blais-Stevens, A., Clague, J.J., 2001. Paleoseismic signature in late Holocene sediment cores from Saanich Inlet, British Columbia. Mar. Geol. 175 (1-4), 131. 
Bookhagen, B., Echtler, H.P., Melnick, D., Strecker, M.R., Spencer, J.Q.G., 2006. Using uplifted Holocene beach berms for paleoseismic analysis on the Santa María Island, south-central Chile. Geophys. Res. Lett. 33, L15302.

Campos, J., Hatzfeld, D., Madariaga, R., López, G., Kausel, E., Zollo, A., Iannacone, G., Fromm, G., Barrientos, S., Lyon-Caen, H., 2002. A seismological study of the 1835 seismic gap in south-central Chile. Phys. Earth Planet. Inter. 132, 177-195.

Cifuentes, I.L., 1989. The 1960 Chilean earthquake. J. Geophys. Res. 94, 665-680.

Cisternas, M., Atwater, B.F., Torrejon, F., Sawai, Y., Machuca, G., Lagos, M., Eipert, A., Youlton, C., Salgado, I., Kamataki, T., Shishikura, M., Rajendran, C.P., Malik, J.K., Rizal, Y., Husni, M., 2005. Predecessors of the giant 1960 Chile earthquake. Nature 437, 404.

Comte, D., Eisenberg, A., Lorca, E., Pardo, M., Ponce, L., Saragoni, R., Singh, S., Suárez, G., 1986. The 1985 central Chile earthquake, a repeat of previous earthquakes in the region? Science 233, 449-453.

Einsele, G., 1996. Event deposits: the role of sediment supply and relative sealevel changes-overview. Sediment. Geol. 104 (1-4), 11.

Einsele, G., Chough, S.K., Shiki, T., 1996. Depositional events and their recordsan introduction. Sediment. Geol. 104 (1-4), 1

Glodny, J., Echtler, H., Collao, S., Ardiles, M., Buron, P., Figueroa, O., in press. Differential Late Paleozoic active margin evolution in South-Central Chile $\left(37^{\circ} \mathrm{S}-40^{\circ} \mathrm{S}\right)$ - The Lanalhue Fault Zone. J. South Amer. Earth Sc.

Goldfinger, C., Nelson, C.H., Johnson, J.E., 2003. Holocene earthquake records from the Cascadia Subduction Zone and Northern San Andreas Fault based on precise dating of offshore turbidites. Annu. Rev. Earth Planet. Sci. 31 (1), $555-577$.

Goldfinger, C., Morey, A.E., Nelson, C.H., Gutierrez-Pastor, J., Johnson, J.E., Karabanov, E., Chaytor, J., Eriksson, A., 2007. Rupture lengths and temporal history of significant earthquakes on the offshore and north coast segments of the Northern San Andreas Fault based on turbidite stratigraphy. Earth Planet. Sci. Lett. 254 (1-2), 9.

Gorsline, D.S., De Diego, T., Nava-Sanchez, E.H., 2000. Seismically triggered turbidites in small margin basins: Alfonso Basin, Western Gulf of California and Santa Monica Basin, California Borderland. Sediment. Geol. 135 (1-4), 21.

Grevemeyer, I., Kaul, N., Diaz-Naveas, J.L., Villinger, H.W., Ranero, C.R., Reichert, C., 2005. Heat flow and bending-related faulting at subduction trenches: case studies offshore Nicaragua and central Chile. Earth Planet. Sci. Lett. 236 (1-2), 238-248.

Hackney, R.I., Echtler, H.P., Franz, G., Götze, H.J., Lucassen, F., Marchenko, D., Melnick, D., Meyer, U., Schmidt, S., Tasarova, Z., Tassara, A., Wienicke, S., 2006. The segmented overriding plate and coupling at the South-Central Chilean Margin ( $\left.36-42^{\circ} \mathrm{S}\right)$. In: Oncken, G.C.O., Franz, G., Giese, P., Götze, H.-J., Ramos, V.A., Strecker, M.R., Wigger, P. (Eds.), The Andes-Active Subduction Orogeny. Springer-Verlag.

Hebbeln, D., Lamy, F., Mohtadi, M., Echtler, H., 2007. Tracing the impact of glacial-interglacial climate variability on erosion of the southern Andes. Geology 35 (2), 131-134.

Hughen, K., Lehman, S., Southon, J., Overpeck, J., Marchal, O., Herring, C., Turnbull, J., 2004. 14C activity and global carbon cycle changes over the past 50,000 years. Science 303, 202-207.

Huh, C.A., Su, C.C., Liang, W.T., Ling, C.Y., 2004. Linkages between turbidites in the southern Okinawa Trough and submarine earthquakes. Geophys. Res. Lett. 31 (L12304).

Inouchi, Y., Kinugasa, Y., Kumon, F., Nakano, S., Yasumatsu, S., Shiki, T., 1996. Turbidites as records of intense palaeoearthquakes in Lake Biwa, Japan. Sediment. Geol. 104 (1-4), 117.

Kelleher, J.A., 1972. Rupture zones of large South American earthquakes and some predictions. J. Geophys. Res. 77, 2089-2103.

Krawczyk, C.M., SPOC-Team, 2003. Amphibious seismic survey images plate interface at 1960 Chile earthquake. EOS Trans. 84 (32/301), 304-305.

Lamb, S., Davis, P., 2003. Cenozoic climate change as a possible cause for the rise of the Andes. Nature 425, 792.

Lamy, F., Hebbeln, D., Wefer, G., 1999. High-resolution marine record of climatic change in mid-latitude Chile during the last 28,000 years based on terrigenous sediment parameters. Quat. Res. 51 (1), 83.

Lamy, F., Hebbeln, D., Rohl, U., Wefer, G., 2001. Holocene rainfall variability in southern Chile: a marine record of latitudinal shifts of the Southern Westerlies. Earth Planet. Sci. Lett. 185 (3-4), 369.
Lamy, F., Rühlemann, C., Hebbeln, D., Wefer, G., 2002. High- and low-latitude climate control on the position of the southern Peru-Chile Current during the Holocene. Paleoceanography 17.

Lamy, F., Kaiser, J., Ninnemann, U., Hebbeln, D., Arz, H.W., Stoner, J., 2004 Antarctic timing of surface water changes off Chile and Patagonian ice sheet response. Science 304, 1959-1962.

Lee, H.J., Edwards, B.D., 1986. Regional method to assess offshore slope stability. J. Geotech. Eng. 112, 489-509.

Lee, H.J., Chough, S.K., Yoon, S.H., 1996. Slope-stability change from late Pleistocene to Holocene in the Ulleung Basin, East Sea (Japan Sea) Sediment. Geol. 104 (1-4), 39.

Lomnitz, C., 1970. Major earthquakes and tsunamis in Chile during the period 1535-1955. Geol. Rundsch. 59, 938-960.

Lomnitz, C., 2004. Major earthquakes of Chile: a historical survey, 1535-1960. Seismol. Res. Lett. 75 (3), 368-378.

Markgraf, V., 1998. Past climates of South America. In: Hobbs, J.E., Lindesay, J.A., Bridgman, H.A. (Eds.), Climates of the Southern Continents: Present, Past and Future. Wiley, pp. 107-134.

Melnick, D., Bookhagen, B., Echtler, H.P., Strecker, M.R., 2006. Coastal deformation and great subduction earthquakes, Isla Santa María, Chile $\left(37^{\circ}\right.$ S). Geol. Soc. Am. Bull. 118 (11), 1463-1480.

Melnick, D., Echtler, H.P., 2006a. Inversion of forearc basins in south-central Chile caused by rapid glacial age trench fill. Geology 34 (9), 709-712.

Melnick, D., Echtler, H.P., 2006b. Morphotectonic and geologic digital map compilations of the south-central Andes $\left(36^{\circ}-42^{\circ} \mathrm{S}\right)$. In: O. e. a. (Ed.), The Andes-Active Subduction Orogeny. Springer-Verlag, pp. 565-568.

Miller, A., 1976. The climate of Chile. In: Schwerdtfeger, W. (Ed.), World Survey of Climatology, vol. 12. Elsevier, pp. 113-145.

Mix, A.C., Tiedemann, R., Blum, P., et al., 2003. Proc. ODP, Init. Repts., 202. Ocean Drilling Program.

Mohtadi, M., Hebbeln, D., Marchant, M., 2005. Upwelling and productivity along the Peru-Chile Current derived from faunal and isotopic compositions of planktic foraminifera in surface sediments. Mar. Geol. 216 (3), 107.

Muñoz, J., Troncoso, R., Duhart, P., Crignola, P., Farmer, L., Stern, C.R., 2000. The relation of the mid-Tertiary coastal magmatic belt in South-Central Chile to the late Oligocene increase in plate convergence rate. Rev. Geol. Chile 27 (2), 177-203.

Mutti, E., Lucchi, F.R., Seguret, M., Zanzucchi, G., 1984. Seismoturbidites: a new group of resedimented deposits. Mar. Geol. 55 (1-2), 103.

Nakajima, T., Kanai, Y., 2000. Sedimentary features of seismoturbidites triggered by the 1983 and older historical earthquakes in the eastern margin of the Japan Sea. Sediment. Geol. 135 (1-4), 1.

Nelson, A.R., Manley, W.F., 1992. Holocene coseismic and aseismic uplift of Isla Mocha, south-central Chile. Quat. Int. 15-16, 61.

Pahnke, K., Zahn, R., Elderfield, H., Schulz, M., 2003. 340,000-year centennialscale marine record of Southern Hemisphere Climate Oscillation. Science 301, 948-952.

Plafker, G., Savage, J.C., 1970. Mechanism of the Chilean earthquakes of May 21 and 22, 1960. Geol. Soc. Am. Bull. 81 (4), 1001-1030.

Rabassa, J., Clapperton, C., 1990. Quaternary glaciations of the southern Andes. Quat. Sci. Rev. 9, 153-174.

Rauch, K., 2005. Cyclicity of Peru-Chile trench sediments between $36^{\circ}$ and $38^{\circ} \mathrm{S}$ : a footprint of paleoclimatic variations? Geophys. Res. Lett. 32 (8), L08302.

Rehak, K., Strecker, M.R., Echtler, H.P., 2008. Morphotectonic segmentation of an active forearc, $37^{\circ}-41^{\circ} \mathrm{S}$, Chile. Geomorphology $94,98-116$.

Rein, B., Sirocko, F., 2001. In-situ reflectance spectroscopy-analysing techniques for high-resolution pigment logging in sediment cores. Int. J. Earth Sci. (Geol. Rundsch.), 91, 950-954. doi:10.1007/s00531-002-0264-0.

Rein, B., (2003) In-situ Reflektionsspektroskopie und digitale Bildanalyse: Gewinnung hochauflösender Paläoumweltdaten mit fernerkundlichen Methoden, habilitation thesis, 104 pp, Univ. of Mainz, Mainz, Germany.

Ruff, L.J., 1989. Do trench sediments affect great earthquake occurrence in subduction zones? PAGEOPH 129 (1/2), 263-282.

Schweller, W.J., Kulm, L.D., Prince, R.A., 1981. Tectonics, structure and sedimentary framework of the Peru-Chile-Trench. In Nazca Plate: crustal formation and Andean convergence. In: Kulm, L.D., et al. (Ed.), Geol. Soc. America Mem., vol. 154, pp. 323-350. 
Shiki, T., Kumon, F., Inouchi, Y., Kontani, Y., Sakamoto, T., Tateishi, M., Matsubara, H., Fukuyama, K., 2000. Sedimentary features of the seismoturbidites, Lake Biwa, Japan. Sediment. Geol. 135 (1-4), 37.

Stuiver, M., Reimer, P.J., Bard, E., Beck, J.W., Burr, G.S., Hughen, K.A., Kromer, B., McCormac, G., Van der Pflicht, J., Spurk, M., 1998. INTCAL98 radiocarbon age calibration, 24,000-0 cal BP. Radiocarbon 40, 1041-1083.

Stuut, J.B.W., Kasten, S., Lamy, F., Hebbeln, D., 2007. Sources and modes of terrigenous sediment input to the Chilean continental slope. Quat. Int. 161 (1), 67.

Tebbens, S.F., Cande, S.C., 1997. Southeast Pacific tectonic evolution from early Oligocene to Present. J. Geophys. Res. - Solid Earth 102 (B6), 12061-12084

Thornburg, T.M., Kulm, L.D., 1987. Sedimentation in the Chile Trench: petrofacies and provenance. J. Sediment. Petrol. 57 (1), 55-74.

Thornburg, T.M., Kulm, L.D., Hussong, D.M., 1990. Submarine-fan development in the southern Chile Trench: a dynamic interplay of tectonics and sedimentation. Geol. Soc. Am. Bull. 102, 1658-1680.

Vargas, G., Ortlieb, L., Chapron, E., Valdes, J., Marquardt, C., 2005. Paleoseismic inferences from a high-resolution marine sedimentary record in northern Chile (23[degree sign]S). Tectonophysics 399 (1-4), 381.

Veit, H., 1996. Southern Westerlies during the Holocene deduced from geomorphological and pedological studies in the Norte Chico, Northern
Chile (27-33[degree sign]S). Palaeogeogr. Palaeoclimatol. Palaeoecol. $123(1-4), 107$.

Völker, D., Wiedicke, M., Ladage, S., Gaedicke, C., Reichert, C., Rauch, K., Kramer, W., Heubeck, C., 2006. Latitudinal variations in sedimentary processes in the Peru-Chile trench off Central Chile. In: Oncken, G.C.O., Franz, G., Giese, P., Götze, H.-J., Ramos, V.A., Strecker, M.R., Wigger, P. (Eds.), The Andes-Active Subduction Orogeny. Springer-Verlag, pp. 193-216.

Waelbroeck, C., Labeyrie, L., Michel, E., Duplessy, J.C., McManus, J.F., Lambeck, K., Balbon, E., Labracherie, M., 2002. Sea-level and deep water temperature changes derived from benthic foraminifera isotopic records. Quat. Sci. Rev. 21 (1-3), 295.

Wiedicke-Hombach, M., Andruleit, H., Balmaceda, G., Bruns, A., Contardo, X., Cramer, B., Delisle, G., Diaz-Naveas, J.L., Erbacher, J., Fenner, J., Goergens, R., Gomez, C., Harazim, B., Heubeck, C., Kloep, F., Kramer, W., Kus, J., Lückge, A., Mohtadi, M., Mühr, P., Panten, D., Reinhardt, L., Steinmann, D., Stummeyer, J., Zeibig, M., 2002. SO161 - 5 SPOC (Subduction Processes off Chile) Geologie - Geochemie - Wärmestrom. BGR.

Wien, K., Holz, C., Kolling, M., Schulz, H.D., 2006. Age models for pelagites and turbidites from the Cap Timiris Canyon off Mauritania. Mar. Pet. Geol. 23 (3), 337.

Zapata, R.A., 2001. Estudio batimétrico del margen Chileno. Universidad de Chile. 